\title{
REAPPRAISING THE ECLECTIC PARADIGM IN AN AGE OF ALLIANCE CAPITALISM
}

\author{
John H. Dunning* \\ Reading and Rutgers Universities
}

\begin{abstract}
This article discusses the implications of the advent of alliance capitalism for our theorizing about the determinants of MNE activity. In particular, it argues that, due to the increasing porosity of the boundaries of firms, countries and markets, the eclectic, or OLI, paradigm of international production needs to consider more explicitly the competitive advantages arising from the way firms organize their inter-firm transactions, the growing interdependencies of many intermediate product markets, and the widening of the portfolio of the assets of districts, regions and countries to embrace the external economies of interdependent activities.
\end{abstract}

\section{INTRODUCTION}

Over the last decade or so, a number of events have occurred that, viewed collectively, suggest that the world economy may be entering a new phase of market-based capitalism - or, at least, changing its trajectory of the past century. These events recognize no geographical boundaries; and they range from changes in the way in which individual firms organize their production and transactions, to a reconfiguration of location-specific assets and the globalization of many kinds of economic activity.

The preeminent driving force behind these events has been a series of systemic technological and political changes, of which a new generation of telecommunication advances and the demise of central planning in Eastern Europe and China are, perhaps, the most dramatic. But, no less far reaching has been the economic rejuvenation of Japan and the emergence of several new industrial powers - especially from East Asia - whose approach to marketbased capitalism - both at a socio-institutional and a techno-economic level [Freeman and Perez 1988] - is very different from that long practiced by Western nations.

The inter-related and cumulative effects of these phenomena have compelled scholars to reexamine some of their cherished concepts about market-based

\footnotetext{
*John H. Dunning is Emeritus Professor of International Business at the University of Reading, U.K., and State of New Jersey Professor of International Business at Rutgers University, New Jersey, U.S.A. Professor Dunning has been researching into the economics of international direct investment and the multinational enterprise since the $1950 \mathrm{~s}$. He has authored, coauthored, or edited thirty-two books on the subject and on industrial and regional economics. Received: February 1995; Revised: August 1995; Accepted: August 1995.
} 
capitalism, and to do so in two major respects. The first is that the growing acceptance that, by themselves, competitive market forces do not necessarily ensure an optimum innovation-led growth path in a dynamic and uncertain world. This is partly because technology is an endogenous variable - not an exogenous one as assumed in the received literature - and partly because the pressures of frequent and unpredictable technological and political changes do not permit a Pareto optimal allocation of resources [Pigou 1932]. With the acceleration of technological change, and a growing emphasis on institutional learning and continuous product improvement, both the concepts and the policy prescriptions of our forefathers are becoming less relevant each day.

The second revered concept that is now under scrutiny is that the resources and competencies of wealth-creating institutions are largely independent of each other; and that individual enterprises are best able to advance their economic objectives, and those of society, by competition, rather than cooperation. Unlike the first idea, this concept has only been severely challenged over the last decade, although, for more than a century, scholars have acknowledged that the behavior of firms may be influenced by the actions of their competitors [Cournot 1851], while Marshall [1920] was one of the first economists to recognize that the spatial clustering or agglomeration of firms with related interests might yield agglomerative economies and an industrial atmosphere, external to the individual firms, but internal to the cluster.

It is the purpose of this paper to consider some of the implications of the changes now taking place in the global marketplace for our understanding of the determinants of multinational enterprise (MNE) activity; and especially the eclectic paradigm of international production. ${ }^{1}$ The main thrust of the paper is to argue that, although the autonomous firm will continue to be the main unit of analysis for understanding the extent and pattern of foreignowned production, the OLI configuration determining trans-border activities is being increasingly affected by the collaborative production and transactional arrangements between firms; and that these need to be more systematically incorporated into the eclectic paradigm. But, prior to subjecting this idea to closer examination, we briefly outline the underlying assumptions of the extant theory of MNE activity in the mid-1980s.

\section{HIERARCHICAL CAPITALISM}

For most of the present century, the deployment of resources and capabilities in market oriented economies has been shaped by a micro-organizational system known as Fordism and a macro-institutional system known as hierarchical capitalism. ${ }^{2}$ The essential characteristic of both these systems is that the governance of production and transactions is determined by the relative costs and benefits of using markets and firms as alternative organizational modes. In conditions of perfect competition, where exchange and coordination 
costs are zero and where there are no externalities of production or consumption, all transactions will be determined by market forces. Business entities will buy their inputs at arm's-length prices from independent firms and households, and sell their outputs at arm's-length prices to independent purchasers.

In practice, such a governance structure has rarely existed; to some degree, all markets contain some impurities. Such impurities are of two kinds. The first is structural market failure, which arises from the actions of participants in or outside the market to distort the conditions of demand or supply. The second is endemic or natural market failure, where either, given the conditions of supply and demand, the market qua market is unable to organize transactors in an optimal way, or it is difficult to predict the behavior of the participants. Such endemic market failure essentially reflects the presence of uncertainty, externalities, and the inability of producers to fully capture increasing returns to scale in conditions of infinite demand elasticity. It also accepts that bounded rationality, information asymmetries and opportunism are more realistic principles governing economic conduct [Williamson 1985, 1993] than perfect cognition and profit- or utility-maximizing behavior on the part of the transactions in the market.

It is partly to avoid or circumvent such market imperfections, and partly to recoup the gains of a unified governance of interrelated activities, that single activity firms choose to internalize intermediate product markets and, in so doing, become diversified firms. To coordinate these different activities, the administrative system takes on the guise of a hierarchy; and as Chandler [1962, 1990] has well demonstrated, as U.S. firms internalized more markets in the last quarter of the 19th century, so hierarchical capitalism came to replace 'arm's-length' capitalism.

Throughout most of the present century, as economic activity has become increasingly specialized and more complex, and as technological advances and political forces have created more endemic market imperfections, the role of large hierarchies, relative to that of markets, as an organizational modality has intensified. At the firm level, the fully integrated production facilities of enterprises such as the Ford Motor Company ${ }^{3}$ in the 1960s epitomized the raison d'etre for, and the extreme form of, hierarchical capitalism; hence the coining of the term 'Fordism'. At a sectoral level, the proportion of output from most industrial countries supplied by vertically integrated or horizontally diversified firms rose throughout most of the 20th century. ${ }^{4}$ Until the late 1970s, scholars usually considered cooperative forms of organizing economic activity as alternatives to hierarchies or markets, rather than as part and parcel of an organizational system of firms, in which inter-firm and intra-firm transactions complement each other. This, in part, reflected the fact that, in the main, economists viewed the boundary of a firm as the point at which its owners relinquished de jure control over resource harnessing and usage; and, 
to a large extent, this boundary was thought to be coincident with a loss of majority equity ownership. It is not surprising, then, that, for the most part, minority joint ventures were regarded as a second best alternative to full ownership. At the same time, most contractual arrangements were considered as market transactions - even in situations in which there was some element of a continuing and information sharing relationship between the parties to the exchange.

We would mention two other important features of 20th century hierarchical capitalism. The first is that it implicitly assumes that the prosperity of firms depends exclusively on the way in which their management internally organizes the resources and capabilities at their disposal. These include the purchased inputs from other firms and the marketing and distribution of outputs. Admittedly, the behavior of such firms might be affected by the strategies of other firms, e.g., oligopolistic competitors, monopolistic suppliers, large customers, and labor unions. But, with these exceptions, in hierarchical capitalism, the external transactions of firms are assumed to be exogenous, rather than endogenous, to their portfolio of assets and skills, and to the way in which these assets and skills are combined with each other to create further value-added advantages.

The second characteristic of hierarchical capitalism is that firms primarily react to endemic and structural market failure by adopting 'exit'-, rather than 'voice'-type strategies. Hirschman [1970] first introduced this concept of exit and voice to explain the responses of firms and states to threats to their economic sovereignty. He postulated two such responses, viz. 'exit' to a better alternative, and 'voice,' which he defined as any attempt at all to change, rather than escape from, an objectionable state of affairs (p. 30). Borrowing from Hirschman's terminology, we might identify two reactions of firms to the presence of market failure. These are: (i) to 'exit,' where the response is to replace the market by internal administrative fiat, and (ii) to 'voice,' where the response is to work with the market (in this case the buyers of its products or the sellers of its purchases) to reduce or eliminate market failure.

Our reading of the raison d'être for hierarchical capitalism, particularly its U.S. brand, is that it was (and still is) an 'exit' reaction to market failure. ${ }^{5}$ To a limited extent, 'voice' strategies are evident in joint equity ventures and contractual agreements and in compensatory institutional instruments - e.g., futures and insurance markets. But, in general, collaborative production, marketing or innovatory projects or problem solving are eschewed. Contract disputes are usually resolved by litigation procedures rather than by propitiating attempts to remove the cause of the disputes. Competition and adversarial relations, rather than cooperation and synergistic affinities, are the hallmarks of hierarchical capitalism, and this is evident in the conduct of both inter-firm and intra-firm coordination procedures and transactions. Hier- 
archical capitalism rarely interprets the roles of firms and governments as being complementary to each other [World Bank 1992].

It is beyond the scope of this paper either to trace the factors that led to hierarchical capitalism and the scale system of production, or to describe its characteristics in any detail. Suffice to mention that, between the mid-1870s and the early 1970s, a series of technological, organizational and financial events occurred that helped reduce the transaction and coordination costs of multi-activity hierarchies relative to those of arm's-length intermediate product markets. Moreover, in contrast to the craft system of production which preceded it, the main impact of the mass production system was felt in the fabricating or assembling, rather than in the processing sectors. And, it was in the former sectors where - in order to better coordinate the stages of production, to reduce the risks of supply irregularities, and to ensure quality control over downstream operations - firms began to internalize intermediate product markets and to engage in vertical integration and horizontal diversification in order to capture the economies of scope and scale.

We have already asserted that mainstream economic and organizational theorists paid only scant attention to this phenomenon until the post-War II period, ${ }^{6}$ and that much of the credit for such work as was done must go to scholars interested in the explanation of the growth of MNEs. ${ }^{7}$ In the 1950s, both Penrose [1956] and Bye [1958] sought to explain the extension of a firm's territorial boundaries in terms of the perceived gains to be derived from vertical and horizontal integration. Later, Penrose formulated a more general theory of the growth of firms [Penrose 1959]; but, her penetrating insights into the advantages of internalized markets (although she never used this term) ${ }^{8}$ had to wait many years before they were adequately acknowledged. ${ }^{9}$

Since the mid-1970s, there has been a plethora of academic papers and monographs that have tried to interpret the existence and growth of MNEs in terms of the benefits that such firms are perceived to derive from internalizing cross-border intermediate product markets. ${ }^{10}$ Although several scholars have considered cooperative arrangements as alternatives to fully owned affiliates, and as forms of quasi internalization, ${ }^{11}$ for the most part, they have been accommodated in a market/hierarchies transaction costs model, with such arrangements being perceived as a point on a continuum between arm's-length markets and complete hierarchies.

The eclectic paradigm, first put forward by the present author at a Nobel Symposium in 1976, is different from internalization theory ${ }^{12}$ in that it treats the competitive (so called O-specific) advantages of MNEs, apart from that which arise from the act of cross-border internalization, as endogenous rather than as exogenous variables. This means that the paradigm is not just concerned with answering the question of why firms engage in FDI, in preference to other modes of cross-border transactions. It is also concerned with why 
these firms possess unique resources and competencies - relative to their competitors of other nationalities - and why they choose to use at least some of these advantages jointly with a portfolio of foreign-based immobile assets.

At the same time, as so far enunciated, the eclectic paradigm is embedded within a socio-institutional framework of hierarchical capitalism, which, as stated earlier, presumes that the wealth creating and efficiency enhancing properties of an MNE are contained within the jurisdiction of its ownership. Thus, using the OLI nomenclature, except where they are acquired by M\&As, the $O$ advantages of firms are presumed to be created and organized quite independently of their dealings with other firms; the L advantages of countries are assumed to reflect the scope and character of their unconnected immobile assets, and the way in which hierarchies and markets determine their use; and, the propensity of firms to internalize intermediate product markets is based primarily on the presumption that most kinds of market failure ${ }^{13}$ faced by firms are generally regarded by them as immutable, i.e., exogenous. Currently, the eclectic paradigm only peripherally embraces the ways in which the participation of firms in collaborative arrangements, or in networks of economic activity, affect the configuration of the OLI variables facing firms at a given moment of time, or on how this configuration may change over time. Partly, one suspects, this is because the value of such arrangements is difficult to quantify; and, partly because inter-firm transactions have been perceived to be of only marginal significance to the techno-economic production system of Fordism and to the socio-institutional paradigm of hierarchical capitalism.

\section{ALLIANCE CAPITALISM}

As suggested in the introduction, a series of events over the last two decades has led several scholars to suggest that the world is moving to embrace a new trajectory of market capitalism. This has been variously described as alliance, relational, collective, associate and the 'new' capitalism. ${ }^{14} \mathrm{~A}$ critical feature of this new trajectory - which is essentially the outcome of a series of landmark technological advances and of the globalization of many kinds of value-added activity - is that it portrays the organization of production and transactions as involving both cooperation and competition between the leading wealth creating agents. ${ }^{15}$ This view is in marked contrast to that which has dominated the thinking of economists since Adam Smith, whereby collaboration among firms is viewed as a symptom of structural market failure, ${ }^{16}$ rather than as a means of reducing endemic market failure. And, it would be a bold scholar who would argue that most agreements concluded between firms over the last hundred years have been aimed at facilitating rather than inhibiting competition.

But, our reading of the literature suggests that, both the raison d'être for concluding inter-firm alliances, and their consequences for economic welfare, have significantly changed over the last two decades. We would at least 
hypothesize that a powerful contemporary motive for concluding such arrangements is to reduce the transaction and coordinating costs of arm'slength market transactions, and to leverage the assets, skills and experiences of partner firms. Another motive is to create or extend hierarchical control, which may also prompt firms to engage in M\&As. However, cooperative arrangements differ from M\&As in three respects. First, the former usually involve only a part - and sometimes a minor part - of the collaborating firms' activities. Second, they may entail no change in the ownership structure of the participating firms; and third, whereas the hierarchical solution implies an 'exiting' by firms from the dictates of the marketplace, the alliance solution implies a 'voice' strategy of working within these dictates to maximize the benefits of the joint internalization of inter-related activities.

The choice between a hierarchical and alliance modality as a means of lessening arm's-length market failure clearly depends on their respective costs and benefits. The literature on the rationale for joint ventures and non-equity transactions - vis à vis markets and hierarchies - is extensive and well known, and will not be repeated here. ${ }^{17}$ It is, however, generally accepted that the choice rests on a trade-off between the perceived benefits of sharing risks and capital outlays on the one hand, and the costs of a loss of control associated with a reduced (or no) ownership on the other. Partly, the outcome will be influenced by the success of the 'voice' between the participants, as illustrated, for example, by the exchange of information, the division of managerial and financial responsibility, and the distribution of profits. But, in the main, most scholars view the choice as being determined by the most cost-effective way of organizing a portfolio of resources and capabilities.

Another reason for collaborative arrangements, however, has less to do with reducing the coordinating and transaction costs of alternative organizational modalities, and more to do with protecting existing - or gaining new proprietary, or $\mathrm{O}$-specific, advantages. Cooperative alliances have a parallel with strategic asset acquiring FDI: and, according to several researchers, over the past decade, the principal incentives for alliance formation have been to lower transaction costs, develop new skills and to overcome or create barriers to entry in national or international markets. ${ }^{18}$ Sometimes, these alliances take the form of shared ownership, i.e., the merging of firms, or the setting up of greenfield joint ventures. But, since the early 1980s, the great majority of inter-firm associations have tended to be less formal in structure and more specific in scope and purpose. According to research undertaken at MERIT [Hagedoorn 1993a], the goals of most strategic alliances have been to gain access to new and complementary technologies, to speed up innovatory or learning processes and to upgrade the efficiency of particular activities - e.g., research and development (R\&D), marketing and distribution, manufacturing methods, etc. - rather than to enhance the overall prosperity of the participating firms. 
It is, perhaps, worth rehearsing some of the reasons for the spectacular growth of competitiveness-enhancing alliances since 1980. Essentially, these reduce to the impact that technological advances and the globalization of the market economy have had on the organization of economic activity. The consequences of the former - a supply-side phenomenon - have been fivefold; first, to raise the fixed - and particularly the learning and innovatory - costs of a wide range of manufacturing and service activities; second, to increase the interdependence between distinctive technologies that may need to be used jointly to supply a particular product; ${ }^{19}$ third, to enhance the significance of multipurpose, or core, technologies, such as robotization, informatics and biotechnology; fourth, to truncate - and sometimes dramatically $\mathrm{so}^{20}$ - the product life-cycle of a particular product; and fifth, which is partly a consequence of the other four characteristics, and partly a result of the changing needs of consumers to focus on the upgrading of core competencies of firms, and on the way these are organized as a means of improving their global competitive advantages.

One of the main consequences of the globalization of economic activity described earlier has been to force firms to be more dynamically competitive. This is particularly the case for firms from advanced industrial countries, and it is demonstrated in two main ways: first, a more determined effort to raise the efficiency with which they produce their existing products, and second, by the successful innovation of new products and the upgrading of assets and skills throughout their value chains.

This combination of global supply and demand pressures on competitiveness has caused firms - and particularly large hierarchies - to reconsider both the scope and organization of their value-added activities. In particular, the 1980s and early 1990s have seen three major responses. First, there has been a fairly general movement by firms towards the shedding or disinternalization of activities both along and between value chains; and towards the specialization on those activities that require resources and capabilities in which firms already have (or can acquire) a perceived competitive advantage. This is a 'concentrate on critical competency' response. At the same time, because of the interdependence of technological advances, e.g., computeraided design and manufacturing techniques, firms find that they need to assure access to the products over which they have now relinquished control. Firms may also wish to exercise some influence over the quality and price of these products, and over the innovation of new products. This means that disinternalization is frequently replaced, not by arm's-length transactions, but by controlled inter-firm cooperative arrangements. Such agreements are particularly noticeable between firms and their subcontractors in the more technologically advanced and information-intensive sectors [Hagedoorn $1993 \mathrm{~b}] .^{21}$ 
Second, because of competitive pressures, the huge and rising costs of R\&D and speedier rates of obsolescence, firms - particularly in high technology sectors - have been increasingly induced to engage in cross-border alliances. Freeman and Hagedoorn traced 4,192 of these alliances between 1980 and 1989. They found that $42 \%$ were organized through R\&D pacts; that $90 \%$ were between companies from the Triad; and that $63 \%$ were formed during the second half of the 1980s. The majority of the alliances involved large firms competing as oligopolies in global markets. ${ }^{22}$ The need, on the one hand, for operational participation and, on the other, for complementarity, shared learning and an encapsulation of the innovation time span has combined to make the 'voice' strategy of cooperative ventures a particularly suitable mode for sustaining and advancing competitive advantage. ${ }^{23}$ At the same time, to be successful, an 'asset-seeking alliance response' does have implications for governance structures, a point we will take up later in this paper.

The third response of firms to recent events has been to try to widen the markets for their core products, so as to benefit fully from the economies of scale. This is, itself, a cost-reducing strategy. It serves to explain much of market-seeking and strategic asset-acquiring FDI - especially between firms servicing the largest industrial markets - as well as those of minority-owned foreign joint ventures and non-equity arrangements that are intended to gain speedy entry into unchartered and unfamiliar territories. Thus, of the 4,192 alliances identified by Freeman and Hagedoorn, 32\% were geared towards improving access to markets. As might be expected, such alliances were particularly numerous among firms with Japanese partners. Such a 'voice' strategy might be termed a 'market-positioning alliance response.'

Each of the three responses identified has widened the sphere of influence of the firms participating in external partnerships. Such actions have also caused a heightened degree of dependence on firm partners for their own prosperity. Thus, the resources and capabilities of companies such as Philips, IBM and Toyota - each of which has several hundred inter-firm alliances - cannot be considered in isolation. Gomes-Casseres and Leonard-Barton [1994] have identified some eighty recently established learning, supply, and positioning partnerships in the personal digital assistants (PDA) sector alone. ${ }^{24}$ One must also consider the impact that these alliances have had on their internally generated $\mathrm{O}$-specific advantages. The design and performance of the next generation of autos, microchips and computers critically depend on not only the advances in innovatory and manufacturing capabilities of the leading assembling companies, but also on the way these capabilities interact with those of their suppliers. Boeing's competitive advantages in producing the next breed of large passenger aircraft are likely to rest as much on the interaction it has with its suppliers and its customers - e.g., the airlines - as it does on its own technological and commercial strengths. Siemens - a leading producer of mainframe computers - relies heavily on cutting-edge technology supplied by 
Fujitsu. In its venture to explore the seabed, Kennecott's mining consortium brings together a large number of firms supplying very different, but interrelated, technologies from many different sectors. Lorenzoni and Baden Fuller [1995] give several examples of organizations which view their subcontractors as partners in innovation and skill development. ${ }^{25}$

Of course, inter-firm cooperation is not a new phenomenon. What is, perhaps, new is its relative significance as an organizational form, whereby the success of the firms involved is being increasingly judged by each party's ability to generate innovation-led growth; by the range, depth and closeness of the interaction between themselves and their alliance or networking parties; and by the effect that such alliances are having upon overall industrial performance. It is the combination of these factors, taken together with the twin forces of the disinternalization of hierarchical activities and the impressive growth of M\&As to gain access to complementary assets, ${ }^{26}$ which lead us to suggest along with Gerlach [1992] - that the term alliance capitalism might be a more appropriate description of the features of innovation-led capitalism now spreading through the globalizing economy, than the term hierarchical capitalism.

A distinctive feature of alliance capitalism is its governance structure. Within a hierarchy, decisions rest on a pyramid of delegated authority. In establishing and strengthening relationships with other firms, customers and labor unions, success is usually judged by the extent to which the hierarchy is able to obtain its inputs at the least possible cost, and to sell its output at the most profitable price. Relationships between firms and within firms are normally defined by a written contract.

In alliance capitalism, decisions are more likely to rest on a consensus of agreement between the participating parties, and there is rarely any formal structure of authority. Such an agreement is based upon a commitment, on the part of each party, to advance the interests of the alliance; and upon mutual trust, reciprocity and forbearance between the partners. In the modern factory practicing flexible manufacturing or Toyota-like production methods, labor is not thought of as a cog in the wheel, as it is in traditional Fordism, but as a partner in the wealth-producing process. Suppliers are not just expected to produce goods to agreed specifications, but to actively work with the purchasing firms to continually upgrade the quality and/or lower the price of their outputs. Even within the hierarchical firm, technological and organizational imperatives are requiring each function, activity or stage of production to be closely integrated with the other. Thus, for example, the purchasing and R\&D departments may be expected to work with the manufacturing departments on the design and development of new products and production methods. The personnel, finance and production departments each need to be involved in the introduction of new working procedures and incentive arrange- 
ments. At the same time, industrial customers and large wholesale and retail outlets may be expected to play an increasingly significant role in determining the direction and pattern of product improvement.

The growing significance of inter-firm cooperative transaction arrangements would suggest that 'voice,' relative to 'exit,' strategies are becoming more cost effective. This, of course, could be either due to the 'push' factor of the increasing net costs of hierarchical control, or to the 'pull' factor of the reduced costs of alliances. It is likely that both factors have been at work in recent years; but, it can surely be no accident that the thrust towards alliance capitalism first originated in Japan, whose culture especially values such qualities as teamwork, trust, consensus, shared responsibility, loyalty, and commitment, which are the essential ingredients of any successful partnership. These qualities - together with the recognition that, by improving quality control throughout the value chain and cutting inventories to the minimum essentially enabled Japanese producers, particularly in the fabricating sectors, to break into their competitors' markets, and to adopt the production strategies and working practices that conformed to the resource and institutional advantages of their home countries. Indeed, most researchers are agreed that the two most significant competitive advantages of Japanese firms that evolved during the post-World War II period were, first, the way they restructured their production and intra-firm transactions, and second, the way they managed and organized their vertical and horizontal relationships with other firms. ${ }^{27}$

Before considering the implications of the new trajectory of market-based capitalism for our theorizing about MNE activity, we would mention three other trends in economic organization that are also favoring more, rather than less, inter-firm cooperation. The first concerns the renewed importance of small- and medium-size firms in the global economy. ${ }^{28}$ This has led some commentators, notably Naisbitt [1994], to assert that yesterday's commercial behemoths are tomorrow's dinosaurs. The reasoning behind this assertion that 'small is beautiful' is that modern production methods, accelerating technological advances, more demanding consumers and the growing importance of services, are all eroding the advantages of large plants based on a continuous, scale-friendly and relatively inflexible production system.

While accepting that there is some evidence for this contention (for example, much of the growth in employment now taking place in the advanced industrial countries is in small- to medium-size firms) we, like Harrison [1994], are not convinced that the strategic influence of large firms is diminishing. We would prefer to suggest that any restructuring of the activity of large firms reflects their preferences for replacing hierarchical with alliance relationships; and, that an increasing number of small firms are, in fact, part of keiretsu-like networks, which, more often than not, are dominated by large, lead or flagship firms, or as Lorenzoni and Baden Fuller [1995] put it, "strategic centers" 
[D'Cruz and Rugman 1992, 1993]. Many small firms, too, are either spin-offs of large firms, or owe their prosperity to the fact that the latter are frequently their main clients and suppliers of critical assets. The kinds of example one has in mind are the hundreds of second- or third-tier suppliers to the large Japanese automobile companies; ${ }^{29}$ the intricate web of horizontal relationships between the various associated companies of the Japanese 'soga shosa'; the extensive outsourcing of both hardware and software development by the Japanese video game producer Nintendo; the network of knitwear firms in the Modena region of northern Italy; the many hundreds of Asian subcontractors to the giant footwear and apparel firms, e.g., Nike and Benetton. ${ }^{30}$ The competitive advantages of the firms in these and similar groups are closely dependent on the exchange of skills, learning experiences, knowledge, and finance between the firms in the network; and on the example and lead given by the flagship firms.

The second trend is related to the first. It is the growth of spatial clusters of economic activities that offer external or agglomerative economies to firms located within the cluster. The idea, of course, is not new. Marshall paid much attention to it in his study of U.K. industry in the early 20th century [Marshall 1920]. Recently, it has been given a new lease of life by Porter [1990], who considers the presence of related industries as one of the four key determinants of a country's competitive assets; and, by Krugman [1991] who believes that such economies largely explain the geographical specialization of value-added activities. While the evidence on the subnational spatial concentration of particular activities is still fragmentary, such as we have suggests that, in the technology and information-intensive sectors, not only are MNEs creating multiple strategic centers for specialized activities, but such clusters are becoming an increasingly important component of competitiveness [Enright 1994]. The form and extent of the clusters may differ. ${ }^{31}$ Sometimes, they relate to a range of pre-competitive innovatory activities, e.g., science parks; sometimes to very specific sectors, e.g., auto assemblers and component suppliers; ${ }^{32}$ and, sometimes, to entrepreneurial or start-up firms, and cooperative research organizations, e.g., SEMITECH. Sometimes the local networks are contained in a very small geographical area, e.g., financial districts in London and New York; sometimes they spread over a whole region, e.g. the cluster of textile firms in north Italy.

The third trend is the growth of industrial networks. Inter-firm alliances can, range from being simple dyadic relationships to being part of complex, and often overlapping, networks consisting of tens, if not hundreds, of firms. The literature on industrial networks is extensive; ${ }^{33}$ but, up to now, the subject has been mainly approached from a marketing or an organizational, rather than from an economic, perspective. This is, perhaps, one reason why internalization theory and the eclectic paradigm of international production have sometimes been portrayed as alternative approaches to network analysis. But to the 
economist, a network is simply a web of interdependent dyadic relationships. One must admit, this makes theorizing about the behavior of the participants very difficult, but no more so than theorizing about the behavior of oligopolists. It is also true that the economist is primarily concerned with the firm as a unit of analysis; but, this in no way should inhibit him (or her) from considering the implications for the firm when it is a part of a network of related firms.

What is clear, however, is that, as networks of alliances become more important, the composition and behavior of the group of firms becomes a more important determinant of the foreign production of the individual firms comprising the network. Nowhere is this more clearly seen than in the role played by the keiretsu in influencing both the competitive advantages of its member firms, and in the way in which these advantages are created, upgraded and used.

\section{REAPPRAISING THE ECLECTIC PARADIGM}

We now turn to consider the implications of alliance capitalism for our theorizing about the determinants of MNE activity, and, more particularly, for the eclectic paradigm. In brief, the implications are threefold. First, the concept of the competitive, or O-specific, advantages of firms, as traditionally perceived, needs to be broadened to take explicit account of the costs and benefits derived from inter-firm relationships and transactions (both at home and abroad), and particularly those that arise from strategic alliances and networks. Second, the concept of location (or L) advantages of countries, as traditionally perceived, needs to give more weight to the following factors: (1) the territorial embeddedness of interdependent immobile assets in particular geographical areas; ${ }^{34}$ (2) the increasing need for the spatial integration of complex and rapidly changing economic activities; (3) the conditions under which inter-firm competitive enhancing alliances may flourish; and, (4) the role of national and regional authorities in influencing the extent and structure of localized centers of excellence.

Third, the idea that firms internalize intermediate markets, primarily to reduce the transaction and coordination costs of markets, needs to be widened to encompass other - and, more particularly, dynamic and competitiveness enhancing - goals, the attainment of which may be affected by microgovernance structures. The incorporation of external alliances into the theory of internalization presents no real problems, other than semantic ones. Either one treats a non-equity alliance as an extension of intra-firm transactions, and accepts that the theory is concerned less with a de jure concept of hierarchical control and ownership, and more with the de facto ways in which interdependent tangible and intangible assets are harnessed and leveraged; or, one treats the inter-firm alliance as a distinctive organizational mode, and more specifically one which is complementary to, rather than a substitute for, a 
hierarchy. Partly, of course, the choice will depend on the unit of analysis being used. Is it the alliance or the network, per se, in which case the idea of 'group internalization' may be a relevant one? Or, is the unit of analysis the individual enterprises that comprise the alliance or network? For our purposes, we shall take the individual enterprise as the unit of analysis. ${ }^{35}$

Let us now be more specific about the modifications that alliance capitalism seems to require of the eclectic paradigm. We consider each of its components in turn. On the left-hand side of Table 1, we set out some of the more important OLI variables that scholars traditionally have hypothesized to influence the level and structure of MNE activity. Research has shown that the composition and significance of these determinants will differ according to the value of four contextual variables, viz. (1) the kind of MNE activity being considered (market, resource, efficiency or strategic asset seeking), (2) the portfolio of location-bound assets of the countries from which the FDI originates, and in which it is concentrated, (3) the technological and other attributes of the sectors in which it is being directed, and (4) the specific characteristics (including the production, innovatory and ownership strategies) of the firms undertaking the investment.

The variables identified in Table 1 are more than a checklist. They are chosen because a trilogy of extant economic and behavioral theories - viz. the theory of industrial organization and market entry, the theory of location ${ }^{36}$ and the theory of the firm $^{37}$ - suggests that they offer robust explanations of the ownership structure of firms, the location of their activities, and the ways in which they govern the deployment of resources and capabilities within their control or influence. However, until very recently, none of these theories have paid much attention to the role of cooperative agreements in influencing MNE activity.

On the right-hand side of Table 1, we identify some additional OLI variables, which we believe, in the evolving era of alliance capitalism, need to be incorporated into our theorizing about MNE activity. The table shows that not all of the OLI variables listed require modification. Thus, of the Oa-specific variables, we would not expect the formation of strategic partnerships to greatly influence the internal work processes of the participating firms, although technological advances, and the need for continuous product improvement, is likely to demand a closer interaction between related valueadding activities, and may well enhance the contribution of shop-floor labor to raising process productivity. Nor would we expect the proprietary rights of brand ownership, favored access to suppliers, or the financial control procedures of firms to be much affected by cooperative agreements.

By contrast, Oa advantages stemming from a firm's ability to create and organize new knowledge, to maintain and upgrade product quality, to seek out and forge productive linkages with suppliers and customers, especially - in 
TABLE 1

A Reconfiguration of the Eclectic Paradigm of International Production

\section{Ownership-Specific Advantages \\ (of enterprise of one nationality (or affiliates of same) over those of another)}

\section{Hierarchical-Related Advantages}

a. Property right and/or intangible asset advantages $(\mathrm{Oa})$.

Product innovations, production management, organizational and marketing systems, innovatory capacity, non-codifiable knowledge: "bank" of human capital experience; marketing, finance, know-how, etc.

b. Advantages of common governance, i.e., of organizing $\mathrm{Oa}$ with complementary assets $(\mathrm{Ot})$.

(i) Those that branch plants of established enterprises may enjoy over de novo firms. Those due mainly to size, product diversity and learning experiences of enterprise, e.g., economies of scope and specialization.

Exclusive or favored access to inputs, e.g., labor, natural resources, finance, information. Ability to obtain inputs on favored terms (due, e.g., to size or monopsonistic influence). Ability of parent company to conclude productive and cooperative inter-firm relationships e.g., as between Japanese auto assemblers and their suppliers. Exclusive or favored access to product markets. Access to resources of parent company at marginal cost. Synergistic economies (not only in production, but in purchasing, marketing, finance, etc. arrangements).

(ii) Which specifically arise because of multinationality. Multinationality enhances operational flexibility by offering wider opportunities for arbitraging, production shifting and global sourcing of inputs. More favored access to and/or better knowledge about international markets, e.g., for information, finance, labor etc. Ability to take advantage of geographic differences in factor endowments, government intervention, markets, etc. Ability to diversify or reduce risks, e.g., in different currency areas, and creation of options and/or political and cultura scenarios. Ability to learn from societal differences in organizational and managerial processes and systems. Balancing economies of integration with ability to respond to differences in country-specific needs and advantages.
Alliance or Network-Related Advantages

a. Vertical Alliances

(i) Backward access to R\&D, design engineering and training facilities of suppliers. Regular input by them on problem solving and product innovation on the consequences of projected new production processes for component design and manufacturing. New insights into, and monitoring of, developments in materials, and how they might impact on existing products and production processes.

(ii) Forward access to industrial customers, new markets, marketing techniques and distribution channels, particularly in unfamiliar locations or where products need to be adapted to meet local supply capabilities and markets. Advice by customers on product design and performance. Help in strategic market positioning.

\section{b. Horizontal Alliances}

Access to complementary technologies and innovatory capacity. Access to additional capabilities to capture benefits of technology fusion, and to identify new uses for related technologies. Encapsulation of learning and development times. Such inter-firm interaction often generates its own knowledge feedback mechanisms and path dependencies.

c. Networks

(i) of similar firms

Reduced transaction and coordination costs arising from better dissemination and interpretation of knowledge and information, and from mutual support and cooperation between members of network. Improved knowledge about process and product development and markets. Multiple, yet complementary, inputs into innovatory developments and exploitation of new markets. Access to embedded knowledge of members of networks. Opportunities to develop 'niche' R\&D strategies; shared learning and training experiences, e.g., as in the case of cooperative research associations. Networks may also help promote uniform product standards and other collective advantages.

(ii) business districts

As per (i) plus spatial agglomerative economies, e.g., labor market pooling. Access to clusters of specialized intermediate inputs, and linkages with knowledge-based institutions, e.g., universities, technological spill-overs. 


\section{TABLE 1 (continued) \\ A Reconfiguration of the Eclectic Paradigm of International Production}

\section{Internalization Incentive Advantages (i.e., to circumvent or exploit market failure).}

\begin{abstract}
Hierarchical-Related Advantages
Avoidance of search and negotiating costs.

To avoid costs of moral hazard, information asymmetries and adverse selection; and to protect reputation of internalizing firm.

To avoid cost of broken contracts and ensuing litigation.

Buyer uncertainty (about nature and value of inputs (e.g., technology) being sold).

When market does not permit price discrimination.

Need of seller to protect quality of intermediate or final products.

To capture economies of interdependent activities (see b. above).
\end{abstract}

To compensate for absence of future markets.

To avoid or exploit government intervention (e.g., quotas, tariffs, price controls, tax differences, etc.)

To control supplies and conditions of sale of inputs (including technology).

To control market outlets (including those which might be used by competitors).

To be able to engage in practices, e.g., crosssubsidization, predatory pricing, leads and lags, transfer pricing, etc. as a competitive (or anticompetitive) strategy.
Alliance or Network-Related Advantages

While, in some cases, time limited inter-firm cooperative relationships may be a substitute for FDI; in others, they may add to the I incentive advantages of the participating hierarchies, R\&D alliances and networking which may help strengthen the overall competitiveness of the participating firms. Moreover, the growing structural integration of the world economy is requiring firms to go outside their immediate boundaries to capture the complex realities of know-how trading and knowledge exchange in innovation, particularly where intangible assets are tacit and need to speedily adapt competitive enhancing strategies to structural change.

Alliances or network related advantages are those which prompt a 'voice' rather than an 'exit' response to market failure; they also allow many of the advantages of internalization without the inflexibility, bureaucratic or risk-related costs associated with it. Such quasiinternalization is likely to be most successful in cultures in which trust, forbearances, reciprocity and consensus politics are at a premium. It suggests that firms are more appropriately likened to archipelagos linked by causeways rather than self-contained 'islands' of conscious power. At the same time, flagship or lead MNEs, by orchestrating the use of mobile $O$ advantages and immobile advantages, enhance their role as arbitragers of complementary cross-border value-added activities.

\section{Location-Specific Variables (these may favor home or host countries)}

\section{Hierarchical-Related Advantages}

Spatial distribution of natural and created resource endowments and markets.

Input prices, quality and productivity, e.g. labor, energy, materials, components, semi-finished goods.

International transport and communication costs.

Investment incentives and disincentives (including performance requirements, etc.).

Artificial barriers (e.g. import controls) to trade in goods.

Societal and infrastructure provisions (commercial, legal, educational, transport, and communication).

Cross-country ideological, language, cultural, business, political, etc. differences.

Economies of centralization of $R \& D$ production and marketing.

Economic system and policies of government: the institutional framework for resource allocation.
The L-specific advantages of alliances arise essentially from the presence of a portfolio of immobile local complementary assets, which, when organized within a framework of alliances and networks, produce a stimulating and productive industrial atmosphere. The extent and type of business districts, industrial or science parks and the external economies they offer participating firms are examples of these advantages which over time may allow foreign affiliates and crossborder alliances and network relationships to better tap into, and exploit, the comparative technological and organizational advantages of host countries. Networks may also help reduce the information asymmetries and likelihood of opportunism in imperfect markets. They may also create local institutional thickness, intelligent regions and social embeddedness [Amin and Thrift 1994]. 
unfamiliar markets - to externalize risk, to successfully manage a complex portfolio of core assets and value-creating disciplines, and to internalize the skills and learning experiences of other organizations, may be strongly influenced by some kinds of cooperative arrangements. Moreover, each of these advantages may better enable a firm both to engage in transborder activities, and to seek out appropriate agreements to strengthen and consolidate its competitive competencies.

The literature identifies two groups of competitive Ot advantages arising from the way in which a firm combines its own resources and capabilities with those of other firms. The first are those which a firm gains from being a multiactivity enterprise, independently of where these activities are located. Such economies of common governance may enable an established firm of one nationality to penetrate a foreign market more easily than a single activity competitor of the same or of another nationality. The second type of Ot advantage arises as a direct consequence of foreign production. ${ }^{38}$ The impact of alliance capitalism is to offer an additional avenue for firms to acquire and build up both types of advantages - and, normally, to do so with less financial outlay and risk than hierarchical capitalism might require. ${ }^{39}$

It is, however, the second kind of Ot advantage that is the quintessence of both the multiactivity and the multinational firm. The implication is, then, that any decline in hierarchical activity reflects a diminution in the net benefits of internalized markets, which may lead to a 'concentrate on core competency strategy.' It is also implied that other ways of obtaining the advantages are becoming more attractive (for example, as a result of a reduction of other kinds of market failure). In our present context, the switch in organizational form is a reflection of a shift in the techno-economic system of production. As we have already argued, this tends to favor a 'voice,' rather than an 'exit,' response to the inability of markets to cope with the externalities of interdependent activities in the first place.

It is too early to judge the extent to which the economies of synergy (and operational flexibility) are being realized in a more cost-effective way by external partnerships, rather than by hierarchical control. In any event, as we have already stated, many - indeed, perhaps, the majority of - strategic business alliances identified by scholars should not be regarded as substitutes for FDI, as they are directed to achieving very specific purposes.

Turning next to the internalization advantages (I) of MNE activities, it is perhaps here where the cooperative interaction between Japanese firms is most clearly demonstrated as a viable alternative to the full ownership and control favored by U.S. firms. Here, too, it is not so much that inter-firm agreements add to the internalization incentives of firms. It is rather that they may help to achieve the same objective more effectively, or spread the capital and other risks of the participating firms. In other words, inter-firm agreements may 
provide additional avenues for circumventing or lessening market failure where the FDI route is an impractical option.

Clearly, the impact of alliance capitalism on the organization of economic activity will vary according to the type of market failure being considered; it is also likely to be highly industry and country specific. Institutional structures, learning paths, the extent of social and territorial embeddedness, cultural values, and national systems of education and innovation are likely to play an especially important role. In some countries, such as Japan, there is less incentive by firms to internalize markets in order to avoid the costs of broken contracts, or to ensure the quality of subcontracted products. The reason is simply because these types of market failure are minimized by the 'voice' strategies of buyers and sellers, which are built upon mutual interest, trust and forbearance. The keiretsu network of inter-firm competitive interaction sometimes between firms in the same sector and sometimes across sectors - is perhaps one of the most frequently quoted alternatives to hierarchical internalization. Although there is frequently some minority cross-ownership among the networking firms, the relationship is built upon objectives, values and strategies that negate the need for the internalization of some kinds of market failure. At the same time, the extent and pattern of keiretsu ties is likely to vary between industrial sectors. It is, for example, most pronounced in the fabricating sectors (where the number and degree of complexity of transactions are the most numerous) and the least pronounced in the processing sectors. And, it is, perhaps, not without interest that Japanese FDI in Europe - relative to its U.S. counterpart - is concentrated in those sectors in which inter-firm, rather than intra-firm, transactions are the preferred modality of counteracting market failure in Japan [Dunning 1994b].

While it would be inappropriate to generalize from this example, it is nevertheless the case that - again due to the adoption of new and flexible production techniques - American firms in the auto and consumer electronic sectors are disinternalizing parts of their value chains. At the same time, they are reducing the number of major suppliers and delegating more design and innovatory functions to them. ${ }^{40}$ Moreover, Japanese-owned auto assemblers in the U.S. are replicating or modifying the keiretsu-type relationships of their parent companies as more Japanese suppliers have been setting up subsidiaries, or engaging in cooperative agreements with U.S. firms to supply components to the assemblers [Banjerji and Sambharya 1994].

Most certainly, a 'voice' response to market failure is raising the profile of strategic partnerships in the organizational strategies of MNEs. Nevertheless, it is the case that some kinds of benefits of cross-border value-added activity can only be effectively realized through full hierarchical control over such operations. Examples include situations in which path dependency, learning experience and the global control over financial assets and key technologies 
and competencies bring their own O-specific advantages, which, because of possible conflicts of interest, would not be realizable from inter-firm agreements. Such agreements, then, would probably be confined to very specific areas of a firm's value-added activities; and, noticeably, those that are outside its core competencies, need specialized proficiencies, can be closely monitored for quality control, and are too costly to produce internally [Quinn and Hilmer 1994]. But, to achieve and sustain many of the most valuable O-specific advantages of multinational operations, hierarchical control probably will remain the principal mode of internationalization, and this applies as much to the Japanese as it does to U.S.- and European-based MNEs.

We finally consider how the advent of alliance capitalism is affecting the location-specific variables influencing international production. We have already indicated that the received literature generally assumes these variables to be exogenous to individual firms, at least at a given moment of time; although, over time, such firms may affect the $\mathrm{L}$ advantages of particular countries or regions.

There are essentially two main ways in which alliance capitalism may affect, or be affected by, the presence and structure of immobile assets. The first is that it may introduce new L-specific variables, or modify the value of those traditionally considered by location theory. The second is that the response of firms to economic geography may be different because of the impact that external alliances may have upon their competitive strengths and global strategies.

Let us first deal with the first type of effect. Chief among the $\mathrm{L}$ variables affecting MNE activity - and that surveys have revealed have become more significant in the past decade - is the availability of resources and capabilities that investing firms believe are necessary to both upgrade and make best use of their core $\mathrm{O}$-specific advantages. In some cases, these complementary assets, or the rights to their use, can be bought on the open market (e.g., power supplies and transport and communication facilities); but, in others, and noticeably in regimes of rapid technological progress [Teece 1992], the 'continuous handshake' of an alliance relationship, rather than the 'invisible hand' of the market is favored [Gerlach 1992]. Since frequently a foreign direct investment requires the establishment of several of these bilateral relationships, it follows that the positioning of a constellation of related partners becomes a prime locational factor. Where part or all of the constellations are sited in close proximity to each other, then additional benefits may arise. These include not only the static agglomerative economies earlier identified, but also the dynamic externalities associated with the gathering and dissemination of information, and the cross-fertilization of ideas and learning experiences.

The attention given by governments of host countries - or of regions in host countries - to the building of a critical mass of inter-related activities, which is consistent with the perceived dynamic comparative advantage of their location- 
bound assets, and to the use of FDI in order to create or upgrade core competences to advance this goal, is just one illustration of the growing benefits to be derived from inter-firm linkages. ${ }^{41}$ These serve as an L-pull factor. Casual empiricism, both past and present, provides ample examples of how the presence of spatially related business networks attract new investors, and recent evidence unearthed by Wheeler and Mody [1992], Harrison [1994], Lazerson [1993], Herrigel [1994], Audretsch and Feldman [1994], and Enright [1994] confirms these impressions. It also reveals that an innovation-driven industrial economy, which seeks to be fully integrated into world markets, needs to focus more attention on the development of clusters of inter-firm linkages, of intelligent regions and of local institutional thickness [Amin and Thrift 1994].

The new trajectory of capitalism has other implications for the locational requirements of MNE investors. Some of these are set out in Table 1. As a generalization, while traditional production-related variables generally are unaffected or becoming less important, those to do with minimizing transaction and coordination costs of markets or the dysfunctioning of hierarchies, those specific to being part of a group or cluster of related activities, and those that help protect or upgrade the global competitiveness of the investing firm, are becoming more important. ${ }^{42}$

Turning now to the second type of effect that alliance capitalism has on $\mathrm{L}$ advantages, we ask the following question: How far, and in what ways, are the responses of MNEs to the $\mathrm{L}$ advantages of countries themselves changing because of the growing pluralism of corporate organizations? The answer is that such pluralism allows firms more flexibility in their locational strategies, and that the immobile assets of countries will not only affect the extent and pattern of foreign participation, but also its organizational form. Thus, on the one hand, the opportunities for networking in a specific country may increase FDI. This is particularly the case when an MNE acquires a firm that is already part of a network. On the other hand, the potential to network may also reduce FDI, as it may allow a foreign firm to acquire the complementary assets it needs without making an equity stake.

Of the two scenarios, the one which is more likely to occur will, of course, depend on a host of industry, firm and country-specific considerations. But, our point will have been made if it is accepted that the hypothesis of scholars about the response of firms to at least some $\mathrm{L}$-specific variables may need to be modified in the light of the growing significance of non-equity-based cooperative arrangements, and of networks of firms with related interests. We also believe that the ways in which MNEs choose to leverage and use a portfolio of interrelated location-bound assets, with those of their own O-specific advantages and the complementary competencies of external partners, are, themselves, becoming an increasingly important core advantage of such firms. 


\section{CONCLUSIONS}

This paper has suggested that the socio-institutional structure of market-based capitalism is undergoing change. The catalyst is a new wave of multi-purpose generic technological advances and the demands of innovation-led production, which are compelling more cooperation among economic agents. Though part of that cooperation is 'bought' by firms through M\&A activity, the growing significance of inter-firm partnering and of networking is demanding a reexamination of traditional approaches to our understanding of the extent and form of international business activity.

Our discussion has concentrated on only one of these approaches, viz., the eclectic paradigm of international production, and has suggested that this explanatory framework needs to be modified in three main ways. First, the role of innovation in sustaining and upgrading the competitive advantages of firms and countries needs to be better recognized. It also needs to be more explicitly acknowledged that firms may engage in FDI and in cross-border alliances in order to acquire or learn about foreign technology and markets, as well as to exploit their existing competitive advantages. Inter alia, this suggests a strengthening of its analytical underpinnings to encompass a theory of innovation - as, for example, propounded by Nelson and Winter [1982], and Cantwell $[1989,1994]$ - that identifies and evaluates the role of technological accumulation and learning as $\mathrm{O}$-specific advantages of firms, and the role of national education and innovation policies affecting the $\mathrm{L}$ advantages of countries.

Second, the paradigm needs to better recognize that a 'voice' strategy for reducing some kinds of market failure - and particularly those to do with opportunism and information impactness by participants in the market - is a viable alternative to an 'exit' strategy of hierarchical capitalism; and that, like hierarchies, strategic partnerships are intended to reduce endemic market failure, and may help to advance innovatory competitiveness rather than inhibit it. Among other things, this suggests that theories of inter-firm cooperation or collective competition, which tend to address issues of static efficiency [Buckley 1994], need to be widened to incorporate questions of dynamic efficiency, e.g., market positioning.

Third, the eclectic paradigm needs to acknowledge that the traditional assumption that the capabilities of the individual firm are limited to its ownership boundaries (and that, outside these boundaries, factors influencing the firms competitiveness are exogenous to it) is no longer acceptable whenever the quality of a firm's efficiency-related decisions is significantly influenced by the collaborative agreements they have with other firms. The concept of decision taking has implications that go well beyond explaining FDI and international production; indeed, it calls into question some of the fundamental underpinnings of the theory of industrial organization. 
Much of the thrust of this paper has been concerned with suggesting how these three evolving concepts - innovation-led growth, a 'voice' reaction to market failure, and cooperation as a competitiveness-enhancing measure - affect the OLI configuration facing firms engaging, or wishing to engage, in cross-border transactions. In doing so, it has thrown up a number of casual hypotheses as to the kinds of $\mathrm{O}$-specific advantages that are most likely to be affected by interfirm alliances and networks, and about how the opportunities to engage in such alliances or networks may affect, and be affected by, the portfolio of inter-related location-specific assets. Our analysis has also sought to identify some of the implications of the gathering pace of innovation-led production, and of alliance capitalism, for the organization of economic activity. In doing so, it has suggested that the internalization paradigm still remains a powerful tool of analysis, as long as it is widened to incorporate strategic-assetacquiring FDI and the dynamic learning activities of firms, and to more explicitly take account of the conditions under which a 'voice' strategy of interfirm cooperation may be a preferable option to an 'exit' strategy for reducing the transaction and coordination costs of arm's-length markets, and building inter-active learning-based competitiveness. ${ }^{43}$

There has been some exploratory empirical testing, using both field and case study data, of the impact of alliances and networks on the performance of locational and organizational strategies of participating firms. Studies by Gomes-Casseres [1994, 1995] on the global computer and electronics industries; by Gomes-Casseres and Leonard-Barton [1994] on the multimedia sector; by Mowery [1991] on the commercial aircraft industry; by Brooks, Blunden and Bidgood [1993] on the container transport industry; by Shan and Hamilton [1991] and Whittaker and Bower [1994] on the pharmaceutical industry; by Peng [1993] on the role of network and alliance strategies in assisting the transition from a collectivist to a market-based economy; by Helper [1993] on the 'exit' and 'voice' sourcing strategies of the leading autoassemblers; by Enright [1993], Glaismeier [1988], Henderson [1994], Lazerson [1993], Piore and Sabel [1984], Saxenian [1994] and Scott [1993] on the rationale for regional clusters and specialized industrial districts in Europe and the U.S.; and, multiple case studies by a number of authors on the roles of keiretsu-based transactions and relational contracting as alternatives to hierarchies (e.g., Lincoln [1990]) are just a few examples.

But, much more remains to be done. Indeed, it is possible that the basic contention of this paper, viz. that innovation-led production systems and cooperative inter-firm agreements are emerging as the dominant form of marketbased capitalism, is incorrect. At the same time, it would be difficult to deny that important changes - and, for the most part, irreversible technological changes - are afoot in the global economy; and, that these changes are requiring international business scholars to reexamine at least some of the concepts and theories that have dominated the field for the last two decades or more. 


\section{NOTES}

1. As set out, most recently, in Dunning [1993a, Ch. 4].

2. See, e.g., Dunning [1994a] and Gerlach [1992] for a more extensive analysis of this proposition.

3. Especially at River Rouge (U.S.), where its empire included ore and coal mines, 70,000 acres of timberland, saw mills, blast furnaces, glass works, ore and coal barges, and a railway [Williamson 1985].

4. As, for example, is shown by data published in the U.S. Census of Manufacturers and the U.K. Census of Production (various issues).

5. For full details, see Chandler [1962] and Dunning [1994a].

6. At the time it was published [1937], Coase's article on The Nature of the Firm was treated as an 'aberration' by his fellow economists [Williamson 1993]. As Coase himself acknowledged [1993], in the 1980s there was more discussion of his ideas than during the whole of the preceding forty years.

7. I do not know for sure which particular scholar first used the concept of market failure to explain the existence and growth of the MNE. I first came across the concept of internalization in the early 1970s in a chapter by John McManus entitled, 'The Theory of the Multinational Firm,' in an edited volume by Pacquet [McManus 1972].

8. It is also of some interest that Penrose did not cite Coase in any of her work.

9. There were, I think, two reasons for this. The first was that mainstream microeconomists were strongly influenced (one might almost say hidebound) by the static equilibrium models of Chamberlin [1933] and Robinson [1933]; and the second was that Penrose had not formalized her theory in a manner acceptable to her colleagues.

10. Among the most frequently quoted scholars are Buckley and Casson, Hennart, Rugman, and Teece. A summary of the views of the internalization school are contained in Dunning [1993a]. See also Rugman [1981], Hennart [1982], Buckley and Casson [1985], and Casson [1987].

11. See, for example, the contributions to Buckley's edited volume [1994].

12. Elsewhere [Dunning 1993b], we have suggested paradigm is a more appropriate term to apply to explain the reactions of firms to cross-border market failure.

13. Exceptions include structural market failure deliberately engineered by firms and the extent to which they may be able to influence the content and degree of market failure, e.g., by lobbying for particular government action, and by the setting up of compensating institutions, e.g., insurance and future markets, to reduce risk.

14. See especially Best [1990], Gerlach [1992], Lazonick [1991 and 1992], Michalet [1991], Dunning [1994a] and Ruigrok and Van Tulder [1995].

15. Here, we think it appropriate to make the point that the expression alliance capitalism should be perceived partly as a sociocultural phenomenon and partly as a techno-organizational one. The former suggests a change in the ethos and perspective towards the organization of capitalism, and, in particular, towards the relationships between the participating institutions and individuals. The latter embraces the formal structure of the organization of economic activity, including the management of resource allocation and growth. Alliance capitalism is an eclectic (sic) concept. It suggests both cooperation and competition between institutions (including public institutions) and between interested parties within institutions. De facto, it is also leading to a flattening out of the organizational structure of decisiontaking of business enterprises, with a pyramidal chain of command being increasingly replaced by a more heterarchical inter-play between the main participants in decisiontaking. Finally, we would emphasize that we are not suggesting that alliance capitalism means the demise of hierarchies, but rather that the rationale and functions of hierarchies requires a reappraisal in the socioeconomic climate of the global marketplace now emerging. 
16. In the words of Adam Smith [1776] 'people of the same trade seldom meet together, even for merriment and diversion, but the conversation ends in a conspiracy against the public, or in some contrivance to raise prices'.

17. See especially Buckley and Casson [1988], Contractor and Lorange [1988], Kogut [1988], Hennart [1988, 1989] and Hagedoorn [1993a and 1993b].

18. The facts are documented in various publications, e.g., Freeman and Hagedoorn [1992], Hagedoorn [1990, 1993a,b], Gomes-Casseres [1993] and UNCTAD [1993, 1994].

19. Some examples are set out in Dunning [1993a], p. 605 ff. "Optoelectronics, for example, is a marriage of electronics and optics and is yielding important commercial products such as optical fibre communication systems [Kodama 1992]. The latest generation of large commercial aircraft, for example, requires the combined skills of metallurgy, aeronautical engineering and aero-electronics. Current medical advances often need the technological resources of pharmacology, biotechnology, laser technology, and genetic engineering for their successful commercialization. The design and construction of chemical plants involves innovatory inputs from chemical, engineering and materials sectors. New telecommunication devices embrace the latest advances in carbon materials, fibre optics, computer technology, and electronic engineering. Modern industrial building techniques need to draw upon the combined expertise of engineering, materials and production technologies. In its venture to explore the sea-bed, Kennecott's consortium brings together a large number of technical disciplines and firms from many different industrial sectors [Contractor and Lorange 1988]. Since both the consumption and the production of most core technologies usually yield externalities of one kind or another, it follows that one or the other of the firms involved may be prompted to recoup these benefits by integrating the separate activities, particularly those which draw upon the same generic technology."

20. Examples include the rapid obsolescence of successive generations of computers and the information-carrying power of micro-chips.

21. One particularly good example is the pharmaceutical industry, where the large drug companies are increasingly internalizing the most novel and risky types of biotechnology innovations to small specialist firms. In the words of two British researchers [Whittaker and Bower 1994] "The large pharmaceutical companies no longer view themselves as the primary innovators in the industry. . . The biotechnology companies take on the role of supplier of innovatory activity." The authors go on to illustrate the symbiotic supplier/buyer relationship that is developing between the two groups of firms. "The large drug company needs technologically novel products to market and the biotechnology company needs finance, sometimes some ancillary technical expertise in later-stage process development and formulation, skill in handling regulatory agreements and marketing forces (p. 258).

22. For example, of the alliances identified by Freeman and Hagedoorn, $76.3 \%$ were accounted for by $21 \mathrm{MNEs}$, each of whom had concluded 100 or more alliances.

23. At the same time, MNEs have increased the R\&D intensity of their foreign operations, and have set up technological listening posts in the leading innovating countries.

24. The authors assert that such alliances result from the fusion of technologies from computer communications and consumer electronics; and that because no single firm had (or has) the internal capabilities or the time needed to produce a PDA, that it was necessary to form a cluster of 'matching' alliances.

25. In their words "Competitive success requires the integration of multiple capabilities (e.g., innovation, productivity, quality, responsiveness to customers) across internal and external organizational boundaries" (p. 151).

26. Not to mention to preclude competition from gaining such assets.

27. See, for example, several chapters in an edited volume by Encarnation and Mason [1994].

28. As shown by a variety of indices.

29. See, for example, Banjerji and Sambharya [1994]. 
30. For further illustrations, see Hamel [1991], Harrison [1994], Stopford [1995], Whittaker and Bower [1994] and Lorenzoni and Baden Fuller [1995].

31. For an interesting discussion of the differing nature of business districts both in the U.S. and in other countries, see Markusen, Hall, Deitrick and Campbell [1991].

32. It is estimated that $70 \%$ of all Toyota's suppliers are within 100 miles of the Toyota's main assembling complex in Tokyo.

33. See particularly, Forsgren and Johanson [1991], Håkansson and Johanson [1993], Johanson and Mattsson [1987, 1994] and Johanson and Vahlne [1977].

34. In the words of Amin and Thrift [1994], and in the context of the globalizing economy, "centers of geographical agglomeration are centers of representation, interaction and innovation within global production filieres." . . It is their "unique ability to act as a pole of excellence and to offer to the wide collectivity a well consolidated network of contacts, knowledge, structures and institutions underwriting individual entrepreneurship which makes a center a magnet for economic activity" (p. 13)

35. For an examination of the alliance as a unit of analysis, see Gomes-Casseres [1994].

36. Where country-specific characteristics are regarded as endogenous variables, then the theory of international economics becomes relevant. This is the position of Kojima [1978, 1990], who is one of the leading exponents of a trade-related theory of MNE activity.

37. In particular, the transaction cost theories of Coase and Williamson. The resource-based theory of the firm [Wernerfelt 1984; Barney 1991; Peteraf 1993] is much broader and, in many respects, is closer in lineage to industrial organization theory, as it is concerned with explaining the origin of a firm's sustainable competitive advantages in terms of resource heterogeneity, limits to competition, and imperfect resource immobility.

38. It is these latter advantages that internalization economists claim follow from foreign owned production, rather than precede it; although, of course, once established, these advantages may place the $\mathrm{MNE}$ in a more favored position for sequential investment.

39. Of course, in some instances, e.g., jointly funded R\&D projects, the resulting economic rents may also have to be shared.

40. Stopford [1995], drawing upon the World Automotive Components supplement published by the Financial Times on the July 12, 1994, gives several examples of this phenomenon.

41. As is amply realized by the national governments of foreign investment agencies in their attempts to attract foreign firms to locate in their territories.

42 .We accept that it may be difficult to separate the specific effect of alliance capitalism from the other forces influencing the L advantage of countries. This, indeed, is a fertile area for empirical research.

43. According to Storper [1994] those firms, sectors, regions and nations that are able to learn faster and more efficiently become competitive because knowledge is scarce and, therefore, cannot be imitated by new entrants or transferred by codified and formal channels to other firms, regions or nations.

\section{REFERENCES}

Amin, Ash \& Nigel Thrift, editors. 1994. Globalization, institutions and regional development in Europe. Oxford: Oxford University Press.

Audretsch, David B. \& Maryann P. Feldman. 1994. External economies and spatial clustering. A. In P. R. Krugman \& A. Venables, editors, The location of economic activity: New theories and evidence. London: Center of Economic Policy Research, CPER.

Banjerji, K. \& R. B. Sambharya. 1994. Vertical keiretsu and international market entry: The case of the Japanese automobile industry. Mimeo. Virginia \& New Jersey: West Virginia and Rutgers Universities. 
Barney, Jay B. 1991. Firm resources and sustained competitive advantage. Journal of Management, 17: 99-120.

Bartness, Andrew \& Keith Cerny. 1993. Building competitive advantage through a global network of capabilities. California Management Review: 78-103.

Best, Michael. 1990. The new competition: Institutions of restructuring. Cambridge, Mass.: Harvard University Press.

Brooks, M. R., R. G. Blunder \& C. I. Bidgood. 1993. Strategic alliances in the global container transport industry. In R. Culpan, editor, Multinational strategic alliances, 221-50. New York \& London: Haworth Press.

Buckley, Peter J., editor. 1994. Cooperative forms of the TNC activity. UNCTC Library on Transnational Corporations. London: Routledge.

\& Mark C. Casson. 1985. The economic theory of the multinational enterprise. London: Macmillan.

1988. A theory of cooperation in international business. In F. J. Contractor \& P. Lorange, editors, Cooperative strategies in international business, 31-53. Lexington, Mass.: D. C. Heath.

Bye, Maurice. 1958. Self-financed multiterritorial units and their time horizon. International Economic Papers, 8: 147-78.

Cantwell, John A. 1989. Technological innovation and multinational corporations. Oxford, U.K.: Basil Blackwell.

editor. 1994. Transnational corporations and innovatory activities. United Nations Library on Transnational Corporations. London: Routledge.

Casson, Mark C. 1987. The firm and the market. Oxford, U.K.: Basil Blackwell.

Chamberlin, Edward. 1933. The theory of monopolistic competition. Boston: Harvard University Press.

Chandler, Alfred D., Jr. 1962. Strategy and structure. Boston: Harvard University Press.

1990. Scale and scope: The dynamics of industrial capitalism. Cambridge, Mass.: Harvard University.

Coase, Ronald H. 1937. The nature of the firm. Economica 4 (November): 386-405.

1988. The firm, the market and the law. Chicago \& London: University of Chicago Press.

1993. The nature of the firm: meaning and influence. In O. E. Williamson \& S. G. Winter, editors, The nature of the firm, 34-74. New York \& Oxford: Oxford University Press.

Contractor, Farok J. \& Peter Lorange. 1988. Cooperative strategies in international business. Lexington, Mass.: D. C. Heath.

Cournot, Antoine A. (trans. N. T. Bacon). 1851. Researches into mathematical principles of the theory of wealth. New York: Macmillan.

D'Cruz, Joseph R. \& Alan M. Rugman. 1992. Business networks for international business. Business Quarterly, 54 (Spring): 101-107. 93-98.

1993. Business networks for global competitiveness. Business Quarterly, 57 (Summer):

Dunning, John H. 1977. Trade, location of economic activity and the multinational enterprise: A search for an eclectic approach. In B. Ohlin, P. O. Hesselborn \& P. M. Wikman., editors, The international allocation of economic activity, 395-418. London: Macmillan. 
1993a. Multinational enterprises and the global economy. Wokingham, Berkshire, U.K.: Addison Wesley.

1993b. Globalization of business. London \& New York: Routledge.

1994a. Globalization, economic restructuring and development (The Prebisch Lecture for 1994). Geneva: UNCTAD.

1994b. The strategy of Japanese and US manufacturing investment in Europe. In M. Mason \& D. Encarnation, editors, Does ownership matter? Japanese multinationals in Europe, 59-86. Oxford, U.K.: Clarendon Press.

Enright, Michael J. 1993. Organization and coordination in geographically concentrated industries. In D. Raff \& N. Lamoreaux, editors. Coordination and information: Historical perspectives on the organization of enterprise. Chicago: Chicago University Press.

1994. Geographic concentration and firm strategy. Paper presented to Prince Bertil Symposium on The Dynamic Firm: The Role of Regions, Technology, Strategy and Organization, Stockholm, June.

Forsgren, Mats \& Jan Johanson, editors. 1991. Managing networks in international business. Philadelphia: Gordon and Breach.

Freeman, Christopher. 1991. Networks of innovators: A synthesis of research issues. Research Policy, 20: 499-514.

\& John Hagedoorn. 1992. Globalization of technology. Working Paper 92.013. Maastricht, The Netherlands: Maastricht Research Institute on Innovation and Technology (MERIT).

Freeman, Christopher \& C. Perez. 1988. Structural crises of adjustment, business cycles, and investment behavior. In G. Dosi, C. Freeman, R. Nelson, G. Silverberg \& L. Soete, editors, Technical change and economic theory. London: Pinter Publishers.

Gerlach, Michael L. 1992. Alliance capitalism: The social organization of Japanese business. Oxford, U.K.: Oxford University Press.

Glaismeier, Amy. 1988. Factors governing the development of high tech industry agglomeratives: A tale of three cities. Regional Studies, 22: 287-301.

Gomes-Casseres, Benjamin. 1993. Computers, alliances and industry evolution. In D. B. Yoffie, Beyond free trade: firms, governments and global competition. Boston: Harvard Business School Press.

1994. Group versus group: How alliance networks compete. Harvard Business Review, July-August: 62-74.

1995. Collective competition: International alliances in high technology. Boston: Harvard University Press.

\& Dorothy Leonard-Barton. 1994. Alliance clusters in multimedia: Safety net or entanglement? Mimeo. Harvard Business School.

Hagedoorn, John. 1990. Organizational modes of inter-firm cooperation and technology transfer. Technovation, 10(1): 17-30.

1993a. Understanding the rationale of strategic technology partnering: Interorganizational modes of cooperation and sectoral differences. Strategic Management Journal, 14: $371-85$.

1993b. Strategic technology alliance of cooperation in high technology industries. In G. Grabher, editor, The embedded firm, 116-37. London \& Boston: Routledge.

\& Joseph Schakenraad. 1993. Strategic technology partnering and international corporate strategies. In K. S. Hughes, editor, European competitiveness, 60-86. Cambridge, U.K.: Cambridge University Press. 
Håkansson, Lars \& Jan Johanson. 1993. The network as a governance structure. In G. Grabher, editor, The embedded firm, 35-51. London \& Boston: Routledge.

Hamel, Gary. 1991. Competition for competence and inter-partner learning with international strategic alliances. Strategic Management Journal, 12: 82-103.

Harrison, Bennett. 1994. Lean and mean: The changing landscape of power in the age of flexibility. New York: Basic Books.

Helper, S. 1993. An exit-voice analysis of supplier relations: The case of the US automobile industry. In G. Grabher, editor, The embedded firm, 141-60. London \& Boston: Routledge.

Henderson, V. 1994. Externalities and industrial development. In P. Krugman \& A. Venables, editors, The location of economic activity: New theories and evidence. London: Centre of Economic Policy Research (CPER).

Hennart, Jean-François. 1982. A theory of the multinational enterprise. Ann Arbor, Mich.: University of Michigan Press.

1988. A transaction costs theory of equity joint ventures. Strategic Management Journal, 9: 361-74.

1989. Can the 'new forms of investment' substitute for the 'old forms': A transaction costs perspective. Journal of International Business Studies, 20(2): 211-33.

Herrigel, G. B. 1994. Power and the redefinition of industrial districts: The case of Baden Württemberg. In G. Grabher, editor, The embedded firm, 227-52. London \& Boston: Routledge.

Hirschman, Albert, O. 1970. Exit, voice and loyalty. Cambridge, Mass.: Harvard University Press.

Johanson, Jan \& Lars G. Mattsson. 1987. Internationalization in industrial systems - network approach. In N. Hood \& J.-E. Vahlne, editors, Strategies in global competition. Chichester \& New York: John Wiley.

1994. The markets-as-networks tradition in Sweden. In G. Laurent, G. L. Lilien \& B. Pras, editors, Research traditions in marketing, 321-46. Dordrecht, Boston: Kluwer.

Johanson, Jan \& Jan-Erik Vahlne. 1977. The internationalization process of the firm - A model of knowledge development and increasing foreign market commitments. Journal of International Business Studies, 8(1): 23-32.

Kobrin, Stephen J. 1993. Beyond geography: Inter-firm networks and the structural integration of the world economy. Working Paper 93-10. Philadelphia: Centre for International Management Studies, University of Pennsylvania.

Kodama, Fumio. 1992. Japan's unique capability to innovate: Technology, fusion and its international implications. In T. S. Arrison, C. F. Bergsten \& M. Harris, editors, Japan's growing technological capability: Implications for the US economy. Washington, D.C.: National Academy Press.

Kogut, Bruce. 1988. Joint ventures: Theoretical and empirical perspectives. Strategic Management Journal: 319-22.

Weijian Shan \& G. Walker. 1993. Knowledge in the network and the network as knowledge. In G. Grabher., editor, The embedded firm, 67-94. London \& New York: Routledge.

Kogut, Bruce \& Sea Jin Chang. 1991. Technological capabilities and Japanese direct investment in the United States. Review of Economics and Statistics, 73(3): 401-13.

Kojima, Kiyoshi. 1978. Direct foreign investment: A Japanese model of multinational business operations. London: Croom Helm. 
1990. Japanese direct investment abroad. Social Science Research Institute Monograph Series 1. Mitaka, Tokyo: International Christian University.

Krugman, Paul R. 1991. Geography and trade. Leuven, Belgium: Leuven University Press \& Cambridge MIT Press.

Lazerson, M. 1993. Factory or putting out? Knitting networks in Modena. In G. Grabher, editor, The embedded firm. London \& Boston: Routledge.

Lazonick, William.1991. Business organization and the myth of the market economy. Cambridge, U.K.: Cambridge University Press.

1992. Business organization and competitive advantage: Capitalist transformation in the twentieth century. In G. Dosi, R. Giannelti \& P. A. Toninelli, editors, Technology and enterprise in a historical perspective, 119-63. Oxford, U.K.: Clarendon Press.

Lincoln, James R. 1990. Japanese organization and organizational theory. Research and Organizational Behavior, 12: 255-94.

Lorenzoni, G. \& Charles Baden Fuller. 1995. Creating a strategic center to manage a web of partners. California Management Review, 37(3): 146-63.

Malecki, Edward J. 1985. Industrial location and corporate organization in high technology industries. Economic Geography, 61(4): 345-69.

Markusen, Ann, Peter Hall, S. Deitrick. \& S. Campbell. 1991. The rise of the gunbelt: The military remapping of industrial America. New York \& Oxford: Oxford University Press.

Marshall, Alfred. 1920. Principles of economics. London: Macmillan.

Mason, Mark \& Dennis Encarnation, editors. 1994. Does ownership matter? Japanese multinationals in Europe. Oxford, U.K.: Clarendon Press.

McManus, John. C. 1972. The theory of the multinational firm. In G. Paquet, editor, The multinational firm and the nation state. Toronto: Collier Macmillan.

Michalet, Charles-Albert. 1991. Strategic partnerships and the changing international process. In L. K. Mytelka, editor, Strategic partnerships: States, firms and international competition. London: Pinter Publishers.

Mody, Ashoka. 1993. Learning through alliances. Journal of Economic Behavior and Organization, 20: 151-70.

Mowery, David C. \& David J. Teece. 1993. Japan's growing capabilities in industrial technology: Implication for US managers and policy makers. California Management Review, Winter: 9-34.

Mytelka, Lynne K. 1991. Strategic partnerships: States, firms, and international competition. London: Pinter Publishers.

Naisbitt, John. 1994. Global paradox: The bigger the world economy, the more political its smallest players. New York: William Morrow.

Nelson, Richard R. \& Sidney G. Winter. 1982. An evolutionary theory of economic change. Cambridge, Mass.: Harvard University Press.

Peng, M. W. 1993. Blurring boundaries: The growth of the firm in planned economies in transition. Mimeo. Washington Center for International Business Education and Research, University of Washington.

Penrose, Edith T. 1956. Foreign investment and growth of the firm. Economic Journal, 60: 220-35.

1959. The theory of the growth of the firm. Oxford, U.K.: Basil Blackwell. 
Perez, C. 1983. Structural changes and the assimilation of new technologies on the economic and social system. Futures, 15: 357-75.

Peteraf, Margaret. 1993. The cornerstones of competitive advantage: A resource based view. Strategic Management Journal, 14: 179-91.

Pigou, Arthur C. 1932 (fourth edition). The economics of welfare. London: Macmillan.

Piore, Michael J. \& Charles. F. Sabel. 1984. The second industrial divide: Possibilities for prosperity. New York: Basic Books.

Porter, Michael. 1990. The competitive advantage of nations. New York: Free Press.

Powell, William W. 1990. Neither market nor hierarchy: Network forms of organization. Research in Organizational Behavior, 12: 245-336.

Quinn, James B. \& F. G. Hilmer. 1994. Strategic outsourcing. Sloan Management Review, Summer: $43-55$.

Robinson, Joan. 1933. The economics of imperfect competition. London: Macmillan.

Ruigrok, Winfried \& Rob van Tulder. 1995 (forthcoming). The logic of international restructuring. London \& New York: Routledge.

Rugman, Alan M. 1981. Inside the multinationals: The economics of internal markets. London: Croom Helm.

Saxenian, Anna Lee. 1991. The origins and dynamics of production networks. In Silicon Valley Research Policy, 20: 423-37.

1994. Regional advantage: Culture and competition in Silicon Valley and Route 128. Cambridge, Mass.: Harvard University Press.

Scott, Allen J. 1993. Technologies: High-technology industry and regional development in Southern California. Berkeley \& Los Angeles: University of California Press.

1994. The geographic foundations of industrial performance. Paper presented to the Prince Bertil Symposium on The Dynamic Firm, the Role of Regions, Technology, Strategy and Organization, Stockholm, June.

Shan, Weijian \& William Hamilton. 1991. Country-specific advantage and international cooperation. Strategic Management Journal, 12(6): 419-32.

Smith, Adam. 1776. An inquiry into the nature and clauses of the wealth of nations, Vol. 1 (1947 edition published by J. M. Dent \& Sons, London).

Stopford, John M. 1995. Competing globally to create and control resources, Mimeo. London Business School.

Storper, M. 1994. Institutions of a learning economy. Los Angeles: School of Public Policy and Social Research, UCLA.

Teece, David J. 1992. Competition, cooperation and innovation. Journal of Economic Behavior and Organization, 18: 1-25.

UNCTAD. 1993. World investment report 1993. Transnational corporations and integrated international production. Geneva: UNCTAD Program on Transnational Corporations.

1994. World investment report 1994. Transnational corporations, employment and the workplace. Geneva: UNCTAD Program on Transnational Corporations.

Weiermar, Karl. 1991. Globalization and new forms of industrial organization. In I. H. Rima, editor, The political economy of global restructuring, Vol. II, 159-71. Aldershot, U.K. \& Brookfield, Vt.: Edward Elgar.

Wernerfelt, Birger. 1984. A resource-based view of the firm. Strategic Management Journal 5(2): 171-80. 
Wheeler, K. \& A. Mody. 1992. International investment and location decisions: The case of US firms. Journal of International Economics, 33: 57-76.

Whittaker, E. \& D. Jane Bower. 1994. A shift to external alliances for product development in the pharmaceutical industry. $R \& D$ Management, 24(3): 249-60.

Williamson, Oliver E. 1985. The economic institutions of capitalism. New York: Free Press.

1993. The logic of economic organization. In O. E. Williamson \& S. E. Winter, editors, The nature of the firm. New York \& Oxford: Oxford University Press.

World Bank. 1992. The World Development Report. New York \& Oxford: Oxford University Press. 